\title{
Food Security in Urban Households: The Role of Women in an Asian Context
}

\section{C.W.Kalansooriya ${ }^{1}$ \\ W. G. V.Gunasekara ${ }^{2}$ (D) \\ P. G. S. A. Jayarathne ${ }^{s}$ (D)}

${ }^{\prime}$ Department of Economics, University of Sri Jayewardenepura, Sri Lanka.

Email:crokalan@sjp.ac.lk

${ }^{2}$ Department of Business Economics, University of Sri Jayewardenepura, Sri Lanka.

Email: gunasekara@sjp.ac.lk

${ }^{s}$ Department of Marketing Management, University of Sri Jayewardenepura, Sri Lanka.

Email:amilaj@sjp.ac.lk

\section{Abstract}

Assuring food security is one of the challenges in low and middle-income countries with their rapid urbanization. The role of women has been identified as a key to food security in rural societies, however, yet to make conclusions in an urban setting. Hence this study tries to analyse the role of women in urban households while addressing the context-specific social and cultural differences of women's role in Asia. The study uses data from Sri Lanka Household Income and Expenditure Survey-2016 and estimates the impact of women's role using the Ordinary Least Square (OLS) method. The relative status of food security of each household is measured using the Household Dietary Diversity Score (HDDS). The study finds a higher level of food security is associated with a higher level of female education. Similarly, households are more food secure when women are more responsible for household income. Further, it reveals that the economic burden on women being the single income earner has not affected on changing the level of food security in their households.

Keywords: Food security, Urban households, Women's role, Asia, Dietary diversity.

JEL Classification: I30; O10.

Citation | C.W.Kalansooriya; W. G. V.Gunasekara; P. G. S. A. Jayarathne (2020). Food Security in Urban Households: The Role of Women in an Asian Context. Economy, 7(1): 11-18.

\section{History:}

Received: 16 January 2020

Revised: 21 February 2020

Accepted: 31 March 2020

Published: 27 April 2020

Licensed: This work is licensed under a Creative Commons

Attribution 3.0 License (cc) E E

Publisher: Asian Online Journal Publishing Group
Acknowledgement: All authors contributed to the conception and design of the study.

Funding: The authors wish to acknowledge that this paper was made possible by the support and guidance given by the "Australia Awards Fellowships Program for Sri Lanka - 2018," which was funded by the Department of Foreign Affairs and Trade, Australia, and co-hosted by Monash University, Australia and the University of Sri Jayewardenepura, Sri Lanka.

Competing Interests: The authors declare that they have no conflict of interests.

Transparency: The authors confirm that the manuscript is an honest, accurate, and transparent account of the study was reported; that no vital features of the study have been omitted; and that any discrepancies from the features of the study have been omitt
study as planned have been explained.

Ethical: This study follows all ethical practices during writing.

\section{Contents}

1. Introduction 12

2. Literature Review 12

3. Methodology 13

4. Results 14

4. Discussion and Conclusion 16

References. 


\section{Contribution of this paper to the literature}

This study adds empirical evidence to the literature on the role of women in urban societies using data from an Asian context.

\section{Introduction}

As the world continues to urbanize, sustainable development challenges will be increasingly concentrated in cities, particularly in the lower-middle-income countries where the pace of urbanization is fastest (UN, 2014). Food security is considered as one such challenge that raised with rapid urban growth and increased urban poverty. Urban food security problems would be worse than those in rural areas (Chatterjeea, Butchera, Wicka, DeSutter, \& Harmonb, 2016) since, unlike in the rural sector, the existence of a safety net, such as rural agriculture, cannot be seen in most urban areas. Rising prices of shelter, transport and healthcare facilities further exacerbate the pressure on the livelihood of the urban dwellers, making them difficult to afford sufficient food (Cohen \& Garrett, 2010; Poulsen, McNab, Clayton, \& Neff, 2015). As a result, hunger, obesity, malnutrition and unhealthy diets coexist in urban areas and affect the poor community (FAO, 2019).

It is widely identified that women play an important role in ensuring food security at the household level in rural areas due to their multiple roles within households as food producers, processors and preparers (ADB, 2014; Ibnouf, 2011; Quisumbing \& Smith, 2007; Smith \& Haddad, 2000). Although the urban sector is not prominent for food-producing, the role women play in assuring food security is still more important to explore because most of the urban women engage in paid jobs and they face a trade-off between income-earning and undertaking their household duties (Gupta, 2006). This is particularly crucial in the Asian context since most of the household food preparation duties are culturally assign for women (Quisumbing, Brown, Feldstein, Haddad, \& Peña, 1995). Given this context, this study tries to analyse the role of urban women in assuring household food security by exploring the context of South Asia.

This study contributes to the literature in two ways. First, it adds context-specific evidence to the prevailing discussion on the role of women in assuring food security in urban households as it explores an Asian context. Secondly, the study uses a large sample of a well-structured survey and the food security is figured using more reliable information on actual food consumption of households. Hence it provides concrete evidence on the impact made by urban women in achieving their household food security.

Sri Lanka serves as a case study for achieving the study objective, since addressing the issues related to urban food security is essential as with increasing growth rate of the urban population in Sri Lanka (UN, 2014). Similarly, examining women, in particular, is vigorous because the role of women in the household may have been changed over the last decades as the statistics indicate that the participation of women in paid employment has been increased in Sri Lanka, particularly in the urban sector (CBSL, 2017).

\section{Literature Review}

\subsection{The Concept of Food Security}

Food security is defined as a situation that exists when all people, at all times, have physical, social and economic access to sufficient safe and nutritious food that meets their dietary needs and food preferences for active and healthy life (FAO, 2006). Food security usually has four dimensions: availability, access, utilization and stability (FAO, 2008). The availability of food refers to having sufficient quantities of food of appropriate quality, supplied through domestic production, imports, food stocks or food aid. Food access encompasses income, expenditure and buying capacity of food by households or individuals. Utilization refers to how nutritional food is consumed in order to make maximum use of it and the way the body makes the most of the various nutrients in the food. The fourth dimension states the stability of the other three dimensions over time. Food security can be investigated at two levels: macro level and micro level. Macro-level food security refers to global, national or regional level food security and mostly targets food availability aspects, while micro aspects focus on household or individual food acquirements and utilization.

\subsection{Food Security in Urban Households}

In earlier times, poverty, food insecurity and malnutrition were viewed as rural problems, with relatively little attention given to such problems in cities. However, with rapid urban growth and increased urban poverty, food insecurity problems have been increasingly recognized as common to urban areas and sometimes urban food security problems are worse than those in rural areas (Atkinson, 1995; Braun, 1993; Chatterjeea et al., 2016; Escaler, Teng, \& Caballero-Anthony, 2010; Levin et al., 1999; Ruel, Garrett, Morris, Maxwell, \& Oshauh, 1998). Hunger, obesity, malnutrition and unhealthy diets all coexist in urban areas, affecting the poor and the affluent (FAO, 2019).

Food security in urban areas is different from that in rural areas because, in the former, it is more interpreted as a matter of food purchase, which is strongly influenced by income, education and consumption patterns and the nature of decision making on food purchases, while in rural areas it is mainly related to food production or availability (Floro \& Swain, 2013). As Escaler et al. (2010) point out, unlike in the countryside, the urban environment is more vulnerable to the global food supply system and price fluctuations resulting from supply discontinuities. Similarly, the empirical literature shows the difference between the determinants of food security in urban and rural sectors (Frimpong \& Asuming-Brempong, 2013). Also evident is the rapid change in consumption patterns in urban areas compared to rural areas (Floro \& Swain, 2013). Because of increased income, there is a higher demand for more expensive sources of nutrients in the urban sector compared to the rural sector, while urban households are more vulnerable to variations in the international market and consumption variations due to changes in global economic event. Furthermore, due to the pressure on households to earn more income and the availability of more economic opportunities in urban areas, there is a greater tendency for women to work outside the home, which may mean they have less time and more difficulty caring for their children (Escaler et al., 2010). 


\subsection{The Role of Women's Employment and Income in Household Food Security}

Empirical studies from several countries, including Kenya, Malawi and Mexico, found a positive relationship between women's income and household nutrition and welfare (Bhagowalia, Menon, Quisumbing, \& Soundararajan, 2010; Djebbari, 2005; Islam, Braun, Thorne-Lyman, \& Ahmed, 2018; Kennedy \& Peters, 1992; Quisumbing et al., 1995; Sraboni, Malapit, Quisumbing, \& Ahmed, 2014). In Sri Lanka, several researchers found that the mother's income proportion had a significant positive impact on household calorie adequacy and relative calorie adequacy of children (Rathnayake \& Weerahewa, 2003) and the level of food security (Kalansooriya \& Chandrakumara, 2014) in the rural sector. As Quisumbing et al. (1995) argue, increasing income generation activities, which translate into higher food expenditure and use of health and education facilities, can improve child nutrition. Not only the amount of income but also the degree of control by women over family income impact directly on improving household food security and nutritional outcomes (Kawarazuka \& Béné, 2010). This is because women tend to spend a significantly higher proportion of their income on food for the family than do men (Quisumbing et al., 1995; Ramachandran, 2008).

Although women's income contributes to a positive change in household food security, there is also a downside to this. According to Mitchodigni et al. (2017) women's involvement in income-earning decreases the time available for household activities, including providing nutrition for children. Gittinger et al. (1990) state that women often reduce the frequency of cooking and increase the amount of food cooked on each occasion to save time for activities that produce income. This, in turn, harms the nutritional status of the family, especially for small children who need more frequent feeding. Engle (2000) argues that, although women's income more positively relates with children's nutrition than does men's income, when women do not have the power to decide how to spend their income on children, wage work harms children's nutritional status.

\subsection{Impact of Women's Education on Household Food Security}

Scholars argue that the correct utilization of acquired food strongly depends on the knowledge and education of the person who manages food preparation in the household - a row that generally falls to women (Mitchodigni et al., 2017). Women with higher education are likely to provide varieties of food thereby increasing the household food security (Mazidi \& Vatanparast, 2018; Olumakaiye \& Ajayi, 2006). A higher level of mothers' education is significantly associated with more expensive diets; either through purchasing more expensive calories from meat, fish, fruit and vegetables, or purchasing more food away from home (Levin et al., 1999). A study by Smith and Haddad (2000) using a cross country regression of 63 developing countries, has found that woman's education accounts for $43 \%$ of the total reduction in child malnutrition. Quisumbing and Meinzen-Dick (2001) find that improving women's education is probably the single most important policy instrument to reduce poverty. The investment in women's education, more than any other factor, increases women's capabilities, expands women's opportunities, and empowers women to exercise their choices, greatly improving food security. Ajaero (2017) finds that improvement in the educational status of women is crucial for maintaining food security even after natural disasters such as floods. The nutritional status of children in Sri Lanka is also found to be positively associated with their mother's education level (Ekanayake, Weerahewa, \& Ariyawardana, 2003; Gunasekera, 1999; Rathnayake \& Weerahewa, 2003).

\subsection{Impact of Women's Status on Household Food Security}

Women's status can be defined as women's decision-making power in the household relative to men (Smith \& Haddad, 2000; Smith, Ramakrishnan, Ndiye, Haddad, \& Martorell, 2003). Since intra-household decision power is delineated primarily based on household headship (Gumede, 2009) an important measure used in food security literature to capture women's status is whether or not the household is headed by a female. Several studies have shown the direct link between female household headship and household food security, mostly in a positive direction: Smith. et al. (2003) studying South Asia, Sub-Saharan Africa and Latin-America, Smith and Haddad (2000) studying 63 developing countries, and Schmeer (2005) on the Philippines support such an argument.

However, Mallick and Rafi (2010) reveal that there is no significant difference in food security levels between male-headed and female-headed households. Indeed, some studies show that female-headed households are more vulnerable to food insecurity and non-income aspects of poverty (Babatunde, Omotesho, Olorunsanya, \& Owotoki, 2008; Doocy \& Lyles, 2017; Felker-Kantor \& Wood, 2012; Kassie, Ndiritu, \& Stage, 2014). The reasons are various. Firstly, the female head who is the main income earner faces disadvantages in the labour market and many productive activities. Secondly, the female head is also responsible for maintaining the household, including household chores and childcare in addition to working outside, and thus she is "activity burdened". Finally, the female household head faces a higher dependency ratio for being the single income earner in the household (Mallick \& Rafi, 2010).

\section{Methodology}

The study uses data gathered from the Household Income and Expenditure Survey conducted in 2016 by the Department of Census and Statistics of Sri Lanka. This survey uses a nationally representative sample and gathers data using two-stage stratified sampling method to cover households and individuals in urban, rural and estate sectors. Further, this survey provides micro-data on demographic characteristics, education, health, individual-level income and household level expenditures of different categories. Since our focus is only on the urban sector the study selected data of 3429 urban households in this survey.

The study uses the Household Dietary Diversity Score (HDDS), which developed by Swindale and Bilinski (2006) to measure the level of household food security. HDDS provides a snapshot of the economic ability of a household to access a variety of foods and it captures the consumption of both macro-and micro-nutrients in line with standard definitions of both food and nutrition security. The HDDS, which is constructed according to international guidelines consists of 12 food groups; cereals and other starchy food, roots and tubers, vegetables, fruits and nuts, meat, eggs, fish and seafood, pulses, milk and milk products, oil and fat, sugar and sugar products and other foods. 
The Construction of the HDDS for each household involved a few steps. The HIES survey provided detailed data of the quantities and expenditures of different food categories consumed weekly by each household. It was quite difficult to aggregate the quantities of different food categories since the measurement scales were varied within a category. For example, some foods had been recorded in grams while others in numbers. Therefore, the expenditures for each food category were aggregated instead of quantities. With the assumption of the amount spent reflects the quality of the food consumed, an advantage of this approach was it was possible to take into account the quality of the good consumed. However, we assumed that the price variation across the urban sector was zero.

To exclude the household size effect, per-capita expenditure was taken and the mean per-capita consumption expenditure of each food categories was calculated by adjusting for outliers. Accordingly, values were assigned as one and zero for each household considering whether the consumption of a particular food category was above its mean value or not. Finally, the HDDS of each household was calculated by summing up the values obtained for all 12 food categories. Accordingly, the maximum score that a household could obtain was 12 and it is the highest food security level that a household can obtain. It is important to note that the level of food security we have generated here is a relative measure as it determines by the sample itself.

We used a multiple linear regression model with the HDDS as the outcome variable to estimate the impact of women in food security. The share of female income in total household income, female education and the household headship, as a measure of female status, were included in the model as independent variables to represent the role of women. The model was controlled for other demographic factors, such as the age of the household head and the ethnic background.

\section{Results}

4.1. Descriptive Measures

A summary of the socio-demographic characteristics of the sample is given in Table 1. Accordingly, three fourth of households headed by males and the majority of the women in households educated up to GCE O/L s. The female share of the household income is just below $25 \%$ of the total income.

Table-1. Characteristics of the sample.

\begin{tabular}{|c|c|c|}
\hline \multicolumn{2}{|c|}{ Socio-demographic factor } & \multirow{2}{*}{$\begin{array}{c}\text { \% of Household } \\
58.7\end{array}$} \\
\hline Ethnicity & Sinhala & \\
\hline & Sri Lankan Tamil & 19.6 \\
\hline & Indian Tamil & 0.8 \\
\hline & Sri Lankan Moors & 19.6 \\
\hline & Other & 1.3 \\
\hline \multirow[t]{2}{*}{ Household Headship } & Male headed & 74 \\
\hline & Female headed & 26 \\
\hline \multirow[t]{5}{*}{ Female education } & Primary or no education & 15.4 \\
\hline & $\mathrm{Up}$ to $\mathrm{O} / \mathrm{L}$ & 55.7 \\
\hline & Up to $\mathrm{A} / \mathrm{L}$ & 23.2 \\
\hline & Degree or above & 5.7 \\
\hline & & Mean \\
\hline \multicolumn{2}{|c|}{ Age of the household head (Years) } & 52.35 \\
\hline \multicolumn{2}{|l|}{ Household size } & 4.08 \\
\hline \multicolumn{2}{|c|}{ Total household income (Rs) } & 63612 \\
\hline \multicolumn{2}{|c|}{ Female share of household income } & 0.23 \\
\hline
\end{tabular}

After adjusting for the outliers, Table 2 shows the mean per capita consumption of each food groups and the percentage of household who reached the mean consumption level. Less than $50 \%$ of households have reached the mean consumption for all food groups except for cereals and pulses. Accordingly, the calculated Household Dietary Diversity Score (HDDS) and the percentage of households which had each HDDS are in Table 3. The distribution approximately follows the shape of the normal distribution Figure 1. The mean HDDS for the whole sample is 5.73 .

Table-2. Mean per capita consumption expenditures.

\begin{tabular}{l|c|c}
\hline \multicolumn{2}{c}{ Table-2. Mean per capita consumption expenditures. } \\
\hline Food category & Mean per capita expenditure (Rs) & \% of household above the mean \\
\hline Cereals and other starchy & 313 & 54 \\
\hline Roots and tubers & 16 & 47 \\
\hline Vegetables & 88 & 47 \\
\hline Fruits and nuts & 37 & 46 \\
\hline Meat & 70 & 46 \\
\hline Eggs & 12 & 46 \\
\hline Fish and sea food & 180 & 48 \\
\hline Pulses & 34 & 50 \\
\hline Milk and milk products & 120 & 46 \\
\hline Oil and fats & 28 & 46 \\
\hline Sugar & 26 & 43 \\
\hline Other products & 321 & 46 \\
\hline
\end{tabular}




\begin{tabular}{c|c|c}
\multicolumn{2}{c}{ Table-3. Household dietary diversity score (HDDS). } \\
\hline HDDS & No of households & \% of households \\
\hline 0 & 42 & 1.22 \\
\hline 1 & 148 & 4.32 \\
\hline 2 & 253 & 7.38 \\
\hline 3 & 372 & 10.85 \\
\hline 4 & 429 & 12.51 \\
\hline 5 & 398 & 11.61 \\
\hline 6 & 420 & 12.25 \\
\hline 7 & 406 & 11.84 \\
\hline 8 & 411 & 11.99 \\
\hline 9 & 291 & 8.49 \\
\hline 10 & 171 & 4.99 \\
\hline 11 & 72 & 2.10 \\
\hline 12 & 16 & 0.47 \\
\hline & 3429 & \\
\hline
\end{tabular}

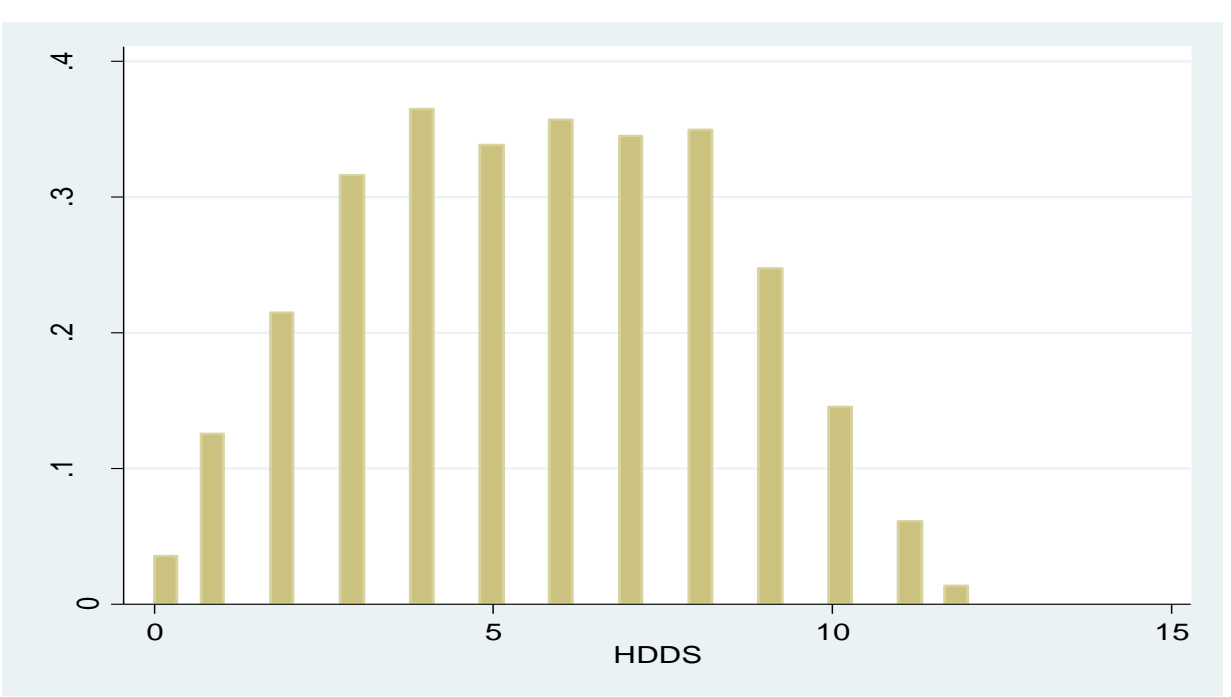

Figure-1. Distribution of HDDS

\subsection{Estimated Model}

Table 4 shows the correlation matrix for the independent variables. Except for female income share and household headship, it does not show a considerable level of correlation between other variables. However, the VIF values prove that the model has not been affected by the multicollinearity issue. Therefore, all the independent variables were included in the model.

Table-4. Correlation for independent variables.

\begin{tabular}{|c|c|c|c|c|c|c|}
\hline$\frac{\stackrel{0}{0}}{\frac{0}{0}}$ & 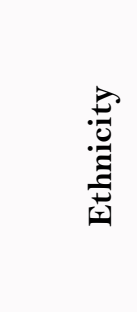 & 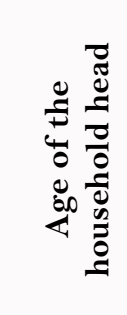 & 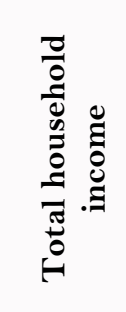 & 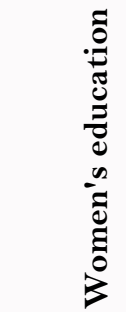 & 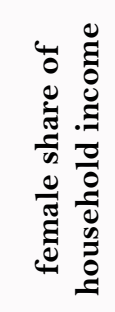 & 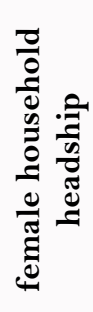 \\
\hline Ethnicity & 1 & & & & & \\
\hline Age of the household head & -0.073 & 1 & & & & \\
\hline Total household income & -0.067 & 0.023 & 1 & & & \\
\hline Woman's education & -0.212 & -0.218 & 0.241 & 1 & & \\
\hline female share of household income & -0.045 & -0.052 & -0.044 & 0.106 & 1 & \\
\hline female household headship & 0.037 & 0.129 & -0.066 & -0.164 & 0.528 & 1 \\
\hline
\end{tabular}

Using HDDS as a dependent variable which measure the level of food security, the model was estimated, and Table 5 shows the results. The estimated model is significant at $1 \%$ significance level. The result indicates a significant increase in the HDDS with female income share and female education. When the female share of total household income increase households tends to increase their HDDS by 0.855 points. Similarly, compared with the households in which women have not educated or educated only up to grade 5, all other households with higher female education level reflect a higher level of HDDS. It is important to note that the higher the level of education, the higher the impact on HDDS. In particular, if women educated up to $\mathrm{O} / \mathrm{L}$, their HDDS is higher by 0.84 points while if she educated up to A/L it is higher by 1.78 points. If she educated up to Degree level, then their HDDS is higher by 2.35 points. The results also show that the HDDS of households in which females are headed by are lower, but the coefficient is not significant. 
Table-5. Result of the estimated model.

\begin{tabular}{|c|c|}
\hline \multicolumn{2}{|l|}{ Dependent Variable : HDDS } \\
\hline Variables & Coefficients \\
\hline \multicolumn{2}{|l|}{ Ethnicity (Reference group= Sinhalese } \\
\hline Sri Lankan Tamil & $\begin{array}{c}-0.324 * * * \\
(0.117)\end{array}$ \\
\hline Indian Tamil & $\begin{array}{l}-0.083 \\
(0.501)\end{array}$ \\
\hline Moors & $\begin{array}{c}-0.541 * * * \\
(0.118)\end{array}$ \\
\hline Others & $\begin{array}{l}-0.193 \\
(0.421)\end{array}$ \\
\hline Age of the Household head & $\begin{array}{c}0.012^{* * *} \\
(0.003)\end{array}$ \\
\hline Total Household Income & $\begin{array}{c}2.40 \mathrm{E}-06^{* * * *} \\
(4.43 \mathrm{e}-07)\end{array}$ \\
\hline \multicolumn{2}{|c|}{ Woman's Education (reference group = Primary or no education) } \\
\hline Up to $\mathrm{GCE} \mathrm{O} / \mathrm{L}$ & $\begin{array}{c}0.844^{* * *} * \\
(0.132)\end{array}$ \\
\hline Up to GCE A/L & $\begin{array}{c}1.778^{* * *} \\
(0.157)\end{array}$ \\
\hline Degree or above & $\begin{array}{c}2.35 * * * \\
(0.234)\end{array}$ \\
\hline Female income share & $\begin{array}{c}0.855^{* * *} \\
(0.157)\end{array}$ \\
\hline Female status (Reference $=$ male headed households) & $\begin{array}{l}-0.162 \\
(0.122)\end{array}$ \\
\hline Constant & $\begin{array}{c}3.902 * * * \\
(0.246)\end{array}$ \\
\hline
\end{tabular}

Considering other variables, ethnic categories, age of the household head and household total income included in the model as control variables. All the other ethnic categories show a lower level of HDDS compared to Sinhalese, however, the coefficients are significant only for Sri Lankan Tamils and Moors. Compared to Sinhalese, the HDDS of Sri Lankan Tamils and Moors are 0.32 points and 0.54 lower respectively. Age of the household is also positively contributed to HDDS, but only a small amount. When age increase by one year the HDDS increase only by 0.01 points. HDDS is positively affected by household income, but only marginally.

\section{Discussion and Conclusion}

This study examines the role of women in ensuring food security in urban households in Sri Lanka. It uses data from 3429 urban households gathered by the Department of Censuses and Statistics under Household Income and Expenditure Survey, 2016. The measurement variable which the study used for food security was HDDS.

The study reveals a positive relationship between female income share and household food security. With increasing female income share, households tend to be food secure, whereas they are food insecure at lower levels of female income or zero female income. This finding is in line with the findings of Islam et al. (2018); Sraboni et al. (2014); Bhagowalia et al. (2010); Djebbari (2005); Quisumbing et al. (1995) and Rathnayake and Weerahewa (2003) who found that female income positively affects household food security. A woman with a higher share of household income means that she may economically strong and can produce a diverse diet for her household members. Therefore, those household reflect a higher level of food security. This result challenge some findings of the literature that shows that women face a trade-off between their income-generating and caring roles (Engle, 2000; Levin et al., 1999; Mitchodigni et al., 2017). It seems that even though women have to work longer hours, and have limited time for household chores such as food preparation, she can still manage her time to provide a diverse diet to her household members. This could be basically because they are culturally more responsible for looking after the food needs of the household. This study further questioned the findings of Mitchodigni et al. (2017) and Variyam, Blaylock, Lin, Ralston, and Smallwood (1999) who also found that household food security is negatively affected when women engage in economic activities. Such contradictory findings may result from differences in the context, data sources used and the timing of the studies.

Women's education has a positive influence on the diversity of the diet consumed by urban households. This may due to educated women paying more attention to preparing a nutritious diet in the household. Women's education was related to the consumption of nutritious food such as fruit, fish and milk products. In particular, the consumption of fruit and milk products in households gradually increased with the increasing education level of women. This is in line with the findings of authors such as Mazidi and Vatanparast (2018); Olumakaiye and Ajayi (2006) and Rathnayake and Weerahewa (2003) who found that women's education has positive impacts on dietary quality.

Women's status in this analysis was defined as the women's power in the household in influencing and controlling household decisions. Accordingly, women's status is decided by taking into account whether the woman is the head of the household or not, assuming that she has a higher status when she is the head than those who not. However, women's status in the household does not show any significant relationship with household food security, implying that female household headship is not a matter of food security at the household level. Such findings match those of Mallick and Rafi (2010) and Garrett and Ruel (1999) who found no difference in food security between male-headed and female-headed households. However, this challenges the findings of scholars such as Smith et al. (2003); Smith and Haddad (2000); Schmeer (2005) which shows that women's status is an important factor in household food security. Also, it questions the researches of Doocy and Lyles (2017); Kassie et al. (2014); 
Babatunde et al. (2008); Levin et al. (1999) and Kennedy and Peters (1992) which show a significant difference in food security levels between male- and female-headed households.

The findings reveal important policy directions to enhance food security at the household level in the urban sector. As the study reveals that households gain a higher level of food security when women are more economically strong and educated, policy actions should target in improving their economic ability and education. Some of the self-employment which they can do while they are at home would be a better solution as it saves women's time for household duties while generating extra income. Similarly, higher attention should be paid to improve education since women's higher education generates positive impacts on household food security. Education could help increase nutritional awareness of women, and thereby increase the nutritional quality of the diet consumed by household members. More importantly, education offers a window for women to obtain better employment, which enhances their ability to earn more income and thereby increase the food security of their households.

\section{References}

ADB. (2014). Urban poverty in Asia, Asian development bank. Retrieved from: https://www.adb.org/sites/default/files/publication/59778/urban-poverty-asia.pdf.

Ajaero, C. K. (2017). A gender perspective on the impact of flood on the food security of households in rural communities of Anambra state, Nigeria. Food Security, 9(4), 685-695.Available at: https://doi.org/10.1007/s12571-017-0695-x.

Atkinson, S. J. (1995). Approaches and actors in urban food security in developing countries. Habitat International, 19(2), 151-163.Available at: https://doi.org/10.1016/0197-3975(94)00063-8.

Babatunde, R., Omotesho, O., Olorunsanya, E., \& Owotoki, G. (2008). Determinants of vulnerability to food insecurity: A genderbased analysis of farming households in Nigeria. Indian Journal of Agricultural Economics, 63(902-2016-67954).

Bhagowalia, P., Menon, P., Quisumbing, A., \& Soundararajan, V. (2010). Unpacking the links between women's empowerment and child nutrition: Evidence using nationally representative data from Bangladesh. Bangladesh: Agricultural \& Applied Economics Association.

Braun, V. J. (1993). Urban food insecurity and malnutrition in developing countries: Trends, policies, and research implications. Washington, D.C: International Food Policy Research Institute.

CBSL. (2017). Annual report. Central Bank of Sri Lanka. Retrieved from: https://www.cbsl.gov.lk/en/publications/economic-and-financialreports/annual-reports/annual-report-2017.

Chatterjeea, A., Butchera, K., Wicka, A. F., DeSutter, T., \& Harmonb, J. (2016). Soil salinity: A threat to global food security. Agronomy Journal, 108(6), 2189-2200.Available at: https://doi.org/10.1177/0956247810380375.

Cohen, M. J., \& Garrett, J. L. (2010). The food price crisis and urban food (in) security. Environment and Urbanization, 22(2), 467-482.

Djebbari, H. (2005). The impact on nutrition of the intra-household distribution of power. IZA Discussion Paper No. 1701. Institute for the Study of Labor (IZA)

Doocy, S., \& Lyles, E. (2017). Humanitarian needs among displaced and female-headed households in government-controlled areas of Syria. American Journal of Public Health, 107(6), 950-959.Available at: https://doi.org/10.2 105/ajph.2017.303710.

Ekanayake, S., Weerahewa, J., \& Ariyawardana, A. (2003). Role of mothers in alleviating child malnutrition: Evidence from Sri Lanka. Retrieved from: http://www.pep-net.org/fileadmin/medias/pdf/files_events/3rd_dakar/Ishara_Ratnayake.pdf.

Engle, P. L. (2000). Achieving urban food and nutrition security in the developing world. Urban women: Balancing work and childcare. International food policy reserch institute. Retrived from http://www.fao.org/fileadmin/templates/ags/docs/MUFN/DOCUMENTS/IFPRI_focuso3.pdf. Accessed June 19, 2018.

Escaler, M., Teng, P., \& Caballero-Anthony, M. (2010). Ensuring urban food security in ASEAN (Association of South East Asian Nations): summary of the findings of the food security expert group meeting held in Singapore 4-5 August, 2010. Food Security, 2(4), 407411.Available at: https://doi.org/10.1007/s12571-010-0083-2.

FAO. (2006). Food security. Policy Brief, Issue 2, Retrieved http://www.fao.org/fileadmin/templates/faoitaly/documents/pdf/pdf_Food_Security_Cocept_Note.pdf.

FAO. (2008). An introduction to the basic concepts of food security in food security information for action practical guides. EC - FAO Food Security Programme. Retrieved from: http://www.fao.org/docrep/o13/al936e/al936eoo.pdf. Accessed June 19, 2018.

FAO. (2019). FAO framework for the urban food agenda. Rome. Retrieved from: https://doi.org/10.4060/ca3151en.

Felker-Kantor, E., \& Wood, C. H. (2012). Improvement in the educational status of women could help households to remain food secure after future floods in Nigeria. Food Security, 4(4), 607-617.

Floro, M. S., \& Swain, R. B. (2013). Food security, gender, and occupational choice among urban low-income households. World Development, 42, 89-99.Available at: https://doi.org/10.1016/j.worlddev.2012.08.005.

Frimpong, S., \& Asuming-Brempong, S. (2013). Comparative study of determinants of food security in rural and urban households of Ashanti region, Ghana. International Journal Econ Manag Science, 2(10), 29-42.

Garrett, J. L., \& Ruel, M. T. (1999). Are determinants of rural and urban food security and nutritional status different? Some insights from Mozambique. World Development, 27(1 1), 1955-1975.Available at: https://doi.org/10.1016/s0305-750x(99)00091-1.

Gittinger, J., Price, C., Sidney, H., Nadine, R., Saito, K., Gittinger, J., . . Saito, K. (1990). Household food security and the role of women (English). World Bank discussion papers; no. WDP 96. Washington,D.C: The World Bank.

Gumede, K. (2009). Intra-household decision making \& development: Analysis of the NIDS Wave 1 dataset discussion, National Income Dynamic Study. Retrieved from: http://www.nids.uct.ac.za/publications/discussion-papers/wave-1-papers/102-nids-discussionpaper-no11/file Accessed 19, June 2018.

Gunasekera, H. R. (1999). Nutrition status of children in Sri Lanka. Sri Lankan Journal of Population Studies, 12, 57-73.

Gupta, S. (2006). Her money, her time: Women's earnings and their housework hours. Social Science Research, 35(4), $975-999$.

Ibnouf, F. O. (2011). Challenges and possibilities for achieving household food security in the Western Sudan region: The role of female farmers. Food Security, 3(2), 215-231.Available at: https://doi.org/10.1007/s 12571-011-0118-3.

Islam, A. H. M., Braun, J. V., Thorne-Lyman, A. L., \& Ahmed, A. U. (2018). Women's empowerment also have positive and significant effects on household dietary diversity. Food Security, $10(33), 701-720$.

Kalansooriya, C. W., \& Chandrakumara, D. P. S. (2014). Women's role in household food security in rural Sri Lanka. International Journal of Multidisciplinary Studies, 1(1), 41-54.Available at: https:// doi.org/10.4038/ijms.v 1i1.31.

Kassie, M., Ndiritu, S. W., \& Stage, J. (2014). What determines gender inequality in household food security in Kenya? Application of exogenous switching treatment regression. World Development, 56, 153-171.Available at: https://doi.org/10.1016/j.worlddev.2013.10.025.

Kawarazuka, N., \& Béné, C. (2010). Linking small-scale fisheries and aquaculture to household nutritional security: An overview. Food Security, 2(4), 343-357.Available at: https://doi.org/10.1007/s 12571-010-0079-y.

Kennedy, E., \& Peters, P. (1992). Household food security and child nutrition: The interaction of income and gender of household head. World Development, 20(8), 1077-1085.Available at: https://doi.org/10.1016/0305-750x(92)90001-c.

Levin, C. E., Ruel, M. T., Morris, S. S., Maxwell, D. G., Armar-Klemesu, M., \& Ahiadeke, C. (1999). Working women in an urban setting: Traders, vendors and food security in Accra. World Development, 27(11), 1977-1991.Available at: https://doi.org/10.1016/s0305$750 x(99) 00096-0$.

Mallick, D., \& Rafi, M. (2010). Are female-headed households more food insecure? Evidence from Bangladesh. World Development, 38(4), 593605.Available at: https://doi.org/10.1016/j.worlddev.2009.11.004.

Mazidi, M., \& Vatanparast, H. (2018). Serum trans-fatty acids level are positively associated with lower food security among american adults. Nutrition $\&^{2}$ Diabetes, 8(1), 1-5.Available at: https://doi.org/10.1038/s41387-017-0008-7. 
Mitchodigni, I. M., Hounkpatin, W. A., Ntandou-Bouzitou, G., Avohou, H., Termote, C., Kennedy, G., \& Hounhouigan, J. (2017). Complementary feeding practices: Determinants of dietary diversity and meal frequency among children aged 6-23 months in Southern Benin. Food Security, 9, $1117-1130$.

Olumakaiye, M. F., \& Ajayi, A. O. (2006). Women's empowerment for household food security: The place of education. Journal of Human Ecology, 19(1), 51-55.Available at: https://doi.org/10.1080/09709274.2006.11905857.

Poulsen, M. N., McNab, P. R., Clayton, M. L., \& Neff, R. A. (2015). A systematic review of urban agriculture and food security impacts in low-income countries. Food Policy, 55, 131-146.Available at: https://doi.org/10.1016/j.foodpol.2015.07.002.

Quisumbing, A. R., \& Meinzen-Dick, R. S. (2001). Overview: Empowering women to achieve food security. Washigton D.C: International Food policy Research Institute.

Quisumbing, A. R., \& Smith, L. (2007). Food policy for developing countries; The role of government in the global food systems. Australian Journal of Agricultural and Resource Economics, 57, 298-300.

Quisumbing, A. R., Brown, L. R., Feldstein, H. S., Haddad, L., \& Peña, C. (1995). Women: The key to food security food policy report. Washington DC: International Food Policy Research Institute.

Ramachandran, N. (2008). Underfed, underpaid and overlooked: Women, the key to food security in south asia. gatekeeper 136: International Institute for Environment and Development.

Rathnayake, I., \& Weerahewa, J. (2003). Intra-household allocation of calories among low income households in Sri Lanka: Impact of female sources of income. Progress Report of Project titled "Globalization and Distribution in Sri Lanka" MIMAP-IDRC. Ottawa, Canada.

Ruel, M. T., Garrett, J. L., Morris, S. S., Maxwell, D., \& Oshauh, A. (1998). Urban challenges to food and nutrition security. FCND Discussion Paper No 51. International food Policy and Research Institute. Washington, D.C.

Schmeer, K. K. (2005). Married women's resource position and household food expenditures in Cebu, Philippines. Journal of Marriage and Family, 67(2), 399-409.Available at: https://doi.org/10.1111/j.0022-2445.2005.00124.x.

Smith, L. C., \& Haddad, L. J. (2000). Explaining child malnutrition in developing countries: A cross-country analysis. Discussion Paper 1-107.

Smith, L. C., Ramakrishnan, U., Ndiye, A., Haddad, L., \& Martorell, R. (2003). The importance of women's status for child nutrition in developing countries research report. Washigton DC: IFPRI.

Sraboni, E., Malapit, H. J., Quisumbing, A. R., \& Ahmed, A. U. (2014). Women’s empowerment in agriculture: What role for food security in Bangladesh? World Development, 61, 11-52.Available at: https://doi.org/10.2139/ssrn.2373183.

Swindale, A., \& Bilinski, P. (2006). Household dietary diversity score (HDDS) for measurement of household food success: Indicator guide, Food and Nutrition Technical Assistant Unit (Vol. 2). Washington DC: Academy for Educational Development.

UN. (2014). World urbanization prospects: The 2014 revision, highlights. United Nations: Department of Economic and Social Affairs, Population Division (ST/ESA/SER.A/352).

Variyam, J. N., Blaylock, J., Lin, B. H., Ralston, K., \& Smallwood, D. (1999). Mother's nutrition knowledge and children's dietary intakes. American Journal of Agricultural Economics, 81(2), 373-384. 